\title{
NITROGEN MINERALIZATION IN SOILS AMENDED WITH SUNNHEMP, VELVET BEAN AND COMMON BEAN RESIDUES
}

\author{
Edmilson José Ambrosano ${ }^{1,5 *}$; Paulo Cesar Ocheuze Trivelin2,5; Heitor Cantarella ${ }^{3,5}$; Gláucia \\ Maria Bovi Ambrosano, 4 ; Takashi Muraoka 2,5 \\ ${ }^{1}$ Centro de Ação Regional, Estação Experimental de Agronomia de Piracicaba - IAC, C.P. 28 - CEP: 13400-970 - \\ Piracicaba, SP. \\ 'Lab. de Isótopos Estáveis - Divisão de Desenvolvimento de Métodos e Técnicas Analíticas e Nucleares, USP/ \\ CENA, C.P. 96 - CEP: 13400-970 - Piracicaba, SP. \\ ${ }^{3}$ Centro de Solos e Recursos Agroambientais - IAC - C.P. 28 - CEP: 13001-970, Campinas, SP. \\ ${ }^{4}$ Depto. de Odontologia Social, Bioestatistica - FOP/UNICAMP, C.P. 52 - CEP: 13414-903 - Piracicaba, SP \\ ${ }^{5} \mathrm{CNPq}$ Fellow. \\ ${ }^{*}$ Corresponding author <edmilson@iac.br>
}

ABSTRACT: Nitrogen $\left({ }^{15} \mathrm{~N}\right.$ ) released from sunnhemp (C rotalaria juncea), velvet bean (Mucuna aterrima) and from Phaseolus bean residues was evaluated after incubation of the plant material in an Eutrudox and a Paleudalf, in a greenhouse experiment with pots containing $6 \mathrm{~kg}$ of air dried soil. Dry matter equivalent to 13 $\mathrm{Mg} \mathrm{ha}^{-1}$ of $P$ haseolus bean residues and the same amount of above ground parts of the leguminous species, associated to 2.7 and $2.2 \mathrm{Mg} \mathrm{ha}^{-1}$ of roots of sunnhemp and velvet bean respectively, were incorporated into the soil. A completely randomized experimental design was adopted, with treatments arranged in a $2 \times 3+1$ factorial, replicated three times. The treatments were the following: two soils (Eutrudox and Paleudalf) and three plant materials: two green-manures (sunnhemp or velvet bean), and Phaseolus bean residues, besides one control without plant incorporation into the soil. For the green-manure treatments there were two subtreatments for each legume species, with ${ }^{15} \mathrm{~N}$ labeling of either shoots or roots. Soil moisture was maintained relatively constant during the experiment al period and the treatments were sampled weekly during 49 days. Total mineral nitrogen in the soil, as well as that derived from the legume plants were determined by isotope dilution. Nitrogen from the velvet bean accounted for a greater proportion of the soil inorganic $\mathrm{N}$; shoots were responsible for most of $\mathrm{N}$ accumulated. Dry bean residues caused immobilization of inorganic $\mathrm{N}$. The leguminous species added were intensively and promptly mineralized preserving the soil native nitrogen. Mineralization of the legume plant $\mathrm{N}$ was greater in the Paleudalf soil than in the Eutrudox.

Key words: mineral nitrogen, green manure, nitrogen-15, N-mineralization

\section{MINERALIZAÇÃO DO NITROGÊNIO EM SOLOS COM INCORPORAÇÃO DE CROTALARIA JUNCEA, MUCUNA-PRETA E RESTOS CULTURAIS DE FEIJOEIRO}

\begin{abstract}
RESUMO: Estudou-se a mineralização do nitrogênio derivado das leguminosas adubo verde (mucuna-preta e crotalária juncea) e de restos culturais de feijoeiro, marcados $\operatorname{com}^{15} \mathrm{~N}$, incorporados em dois solos, Latossolo Vermelho eutroférrico textura argilosa, A moderado (LVef) e Argissolo Vermelho-Amarelo distrófico textura arenosa/média, A moderado (PVad). O trabalho foi desenvolvido em casa de vegetação, em vasos com $6 \mathrm{~kg}$ de terra fina seca ao ar. Incorporou-se aos solos o equivalente a $13 \mathrm{Mg} \mathrm{ha}^{-1}$ de material seco de palha de feijão e mesma quantidade da parte aérea das leguminosas associadas a 2,7 e 2,2 Mg ha ${ }^{-1}$ de raízes de mucuna-preta e crotalária juncea respectivamente. Adotou-se um delineamento experimental inteiramente casualizado com três repetições e os tratamentos originaram-se de um fatorial $2 \times 3+1$ e foram os seguintes: dois solos (LV ef e PV ad) e incorporação de três tipos de leguminosas, sendo dois adubos verdes (mucunapreta e crotalária juncea), e resíduo cultural de feijoeiro, além de uma testemunha sem adição de material vegetal. Os tratamentos com adubos verdes foram divididos em subtratamentos com marcação isotópica independentes da parte aérea e raízes. Os solos foram incubados por 49 dias fazendo-se sete amostragens em intervalos de sete dias. A palha de feijão causou imobilização do N-mineral no solo. A mucuna-preta contribuiu em maior proporção do nitrogênio mineral do solo, principalmente a parte aérea. O N do material vegetal das leguminosas foi mineralizado mais intensamente, preservando o nitrogênio presente no material orgânico original dos solos. A mineralização das leguminosas foi maior no solo Argissolo Vermelho-Amarelo. Palavras-chave: nitrogênio mineral, adubo verde, nitrogênio-15, mineralização de nitrogênio
\end{abstract}

\section{INTRODUCTION}

Nitrogen is the nutrient absorbed in highest amounts by plants. However, in most regions of Brazil, nitrogen fertilizer recommendation is based on very general studies, disregarding soil analysis, but using information on land use history, expected yield and cultivated crop (Cantarella, 1993).

Despite the high nitrogen contents of soils, most $\mathrm{N}$ is in not available forms. Available and non-available 
forms are not necessarily in equilibrium. In addition, because of the high mobility in the soil of the available forms of $\mathrm{N}$, usually there are no direct residual effects of $\mathrm{N}$ fertilizers (Raij, 1981).

Nitrogen applied to the soil, either as plant or other organic residues or as mineral fertilizers, can be used by plants, lost either by leaching or volatilization, or be microbiologically immobilized, gradually changing into stable forms. In general, plants absorb around 50\% of the mineral nitrogen applied to the soil, $25 \%$ are lost by different mechanisms, and $25 \%$ remain in the soil in more or less stable forms (Azam et al., 1985).

Mineralization of organic $\mathrm{N}$ of the plant material added to the soil is initially fast, because of the breakdown of the more easily decomposable components, but it slows down subsequently until stabilization of the organic residue. In some studies the decomposition curves indicate a very complex process (Amato et al., 1987). Decomposition rates are affected by climate factors, particularly temperature, and by soil properties, such as acidity (Jenkinson \& Ayanaba, 1977).

Little emphasis has been given to the effectiveness of the $\mathrm{N}$ supply by green manures (Muraoka, 1984). The use of the ${ }^{15} \mathrm{~N}$ isotope provides precise information about the dynamics of the nitrogen in the soil-plant system. Once the green manure is labeled with the isotope labeling it is possible to distinguish, both in the soil and in the crop, the sources of the nutrient, either soil or green manure, and their respective contributions (Smith et al., 1963 e Fried et al., 1975). Field studies on the incorporation of legume plants labeled with ${ }^{15} \mathrm{~N}$ indicated that 10 to $34 \%$ of the nitrogen from the legume species were recovered by the following crop of either rye or wheat (Ladd et al., 1981b, 1983; Azam et al., 1986, Muller \& Sundman, 1988; Ta \& Faris, 1990). Other reports, carried out in pots showed that rice plants recovered $42 \%$ of the nitrogen of velvet been (Silva, 1991) and corn plants $30 \%$ of the $\mathrm{N}$ of aboveground parts of sunnhemp in podzolic soils and less than $20 \%$ of the $\mathrm{N}$ added as velvet bean roots in an oxisol (Ambrosano, 1995).

Little information is available on the rate of transformation of $\mathrm{N}$ derived from green manures in Brazilian soils, therefore the present study had the objectives of evaluating the nitrogen mineralization and quantifying the transformation of the $\mathrm{N}$ from different incorporated plant residues in two soil types.

\section{MATERIAL AND METHODS}

Two Brazilian soils were used: a clayey Eutrudox and a sandy-clayey Paleudalf. The Eutrudox had the following chemical features: $23 \mathrm{mg} \mathrm{dm}^{-3}$ of resin- $\mathrm{P} ; 32 \mathrm{~g}$ $\mathrm{dm}^{-3}$ of organic matter (OM); pH $5.5\left(\mathrm{CaCl}_{2}\right) ; 4.8 \mathrm{mmol}$ $\left(\mathrm{K}^{+}\right) \mathrm{dm}^{-3} ; 32 \mathrm{mmol}\left(1 / 2 \mathrm{Ca}^{2+}\right) \mathrm{dm}^{-3} ; 14 \mathrm{mmol}\left(1 / 2 \mathrm{Mg}^{2+}\right)$ $\mathrm{dm}^{-3}$; $28 \mathrm{mmol}\left(\mathrm{H}^{+}+1 / 3 \mathrm{Al}^{3+}\right) \mathrm{dm}^{-3}$; CEC $78.8 \mathrm{mmol}(+)$ $\mathrm{dm}^{-3}$ and a base saturation of $64 \%$; the Paleudalf had the following features: $32 \mathrm{mg} \mathrm{dm}{ }^{-3}$ of resine-P; $10 \mathrm{~g} \mathrm{dm}^{-3}$ of $\mathrm{OM}$; pH $4.3\left(\mathrm{CaCl}_{2}\right) ; 1.7 \mathrm{mmol}\left(\mathrm{K}^{+}\right) \mathrm{dm}^{-3} ; 6 \mathrm{mmol}(1 / 2$ $\left.\mathrm{Ca}^{2+}\right) \mathrm{dm}^{-3} ; 1 \mathrm{mmol}\left(1 / 2 \mathrm{Mg}^{2+}\right) \mathrm{dm}^{-3} ; 28 \mathrm{mmol}\left(\mathrm{H}^{+}+1 / 3\right.$ $\left.\mathrm{Al}^{3+}\right) \mathrm{dm}^{-3}$; CEC $36.7 \mathrm{mmol}(+) \mathrm{dm}^{-3}$ and a base saturation of $23 \%$. Soil analysis was carried out by the methods described by Raij et al., (2001).

The mineralization study was carried out in pots containing $6 \mathrm{~kg}$ air dry soil, corresponding to 5,304g and $4,742 \mathrm{~g}$ of oven-dried soil $\left(110^{\circ} \mathrm{C}\right)$ for the Paleudalf and the Eutrudox, respectively. All calculations were based on oven-dried soil.

The mineralization of $\mathrm{N}$ from legume plants incorporated into the two soils was investigated. The legumes included two green manures: velvet bean (Mucuna aterrima) and sunnhemp (Crotalaria juncea), and the common bean (Phaseolus vulgaris) residues (mostly, leaves and stems). For the green manures whole plants, roots included, were incorporated into the soils. A completely randomized factorial design of the $(2 \times 3+$ 1) type was used, with 3 replications: 3 legumes, 2 soils plus one control (soil without the addition of plant material. Treatments with velvet bean and sunnhemp were further divided into two sub-treatments, one with ${ }^{15} \mathrm{~N}$-labeled above-ground parts and non-labeled roots, and another with non-labeled above-ground parts and ${ }^{15} \mathrm{~N}$-labeled roots.

The incubation was performed with $39 \mathrm{~g}$ per pot of dry matter of the above-ground parts of sunnhemp, velvet bean or bean plant residues, equivalent to $13 \mathrm{Mg}$ ha $^{-1}$ of dry matter of organic fertilizer. For the sunnhemp and velvet bean the root parts were also added: 6.6 and $8.6 \mathrm{~g}$ per pot of root dry matter, respectively, corresponding to 2.8 and $2.2 \mathrm{Mg} \mathrm{ha}^{-1}$.

Eight days before incubation the soil of each pot was fertilized with $1.0 \mathrm{~g}$ of $\mathrm{P}\left[\mathrm{Ca}\left(\mathrm{H}_{2} \mathrm{PO}_{4}\right)_{2}\right] ; 700 \mathrm{mg}$ of $\mathrm{K}$ (KCl); $250 \mathrm{mg}$ of $\mathrm{Mg}(\mathrm{MgO}) ; 20 \mathrm{mg}$ of $\mathrm{Zn}\left(\mathrm{ZnSO}_{4} .7 \mathrm{H}_{2} \mathrm{O}\right)$; $20 \mathrm{mg}$ of $\mathrm{Mn}\left(\mathrm{MnSO}_{4} \cdot 3 \mathrm{H}_{2} \mathrm{O}\right) ; 6 \mathrm{mg}$ of $\mathrm{Cu}\left(\mathrm{CuSO}_{4} \cdot 5 \mathrm{H}_{2} \mathrm{O}\right)$; and $2 \mathrm{mg}$ of $\mathrm{B}\left(\mathrm{H}_{3} \mathrm{BO}_{3}\right)$. The Paleudalf soil received also $5.4 \mathrm{~g}$ of a $3: 1$ mixture of $\mathrm{CaCO}_{3}$ and $\mathrm{MgCO}_{3}$, in order to increase base saturation to $70 \%$.

Legume plants were labeled according to the techniques described by Ambrosano et al. (1997), and bean residues $\left({ }^{15} \mathrm{~N}\right)$ were obtained from a previous experiment. Plant material was ground and homogenised with the pot soil. The experimental period was 49 days. Macro and micronutrients in the plant material were determined, as well as the isotopic- $\mathrm{N}$ concentration, according to Ambrosano et al. (1997).

The incubation was carried out in a greenhouse. Soils were moistened to $70 \%$ of the pot water holding capacity and samplings of $70 \mathrm{~g}$ were performed weekly from the topsoil $(0-10 \mathrm{~cm})$.

Statistical analysis used the F-test. The Tukey test was used for comparison of means obtained for bean residues, velvet bean, sunnhemp and control treatments. Polynomial regression was used to evaluate the effect of the incubation period. 
Inorganic $\mathrm{N}\left(\mathrm{NO}_{3}-\mathrm{N}\right.$ and $\left.\mathrm{NH}_{4}-\mathrm{N}\right)$ was extracted from a $50 \mathrm{~g}$ soil sample with $50 \mathrm{ml}$ of $2 \mathrm{~mol} \mathrm{~L}^{-1} \mathrm{KCl}$ solution. The extract was filtered and distilled with $\mathrm{MgO}$ and Devarda's alloy, as described by Buresh et al. (1982). Distilled extracts were used to determine isotopic-N concentration by mass spectrometry by the wet method with alkaline lithium hipobromite (Rittemberg, 1946, modified by the IAEA 1976).

The percentage of inorganic $\mathrm{N}$ in the soil derived from the green manures (\% NDFLM) was calculated as follows [1]:

\section{atom $\%{ }^{15} \mathrm{~N}$ excess of inorganic $\mathrm{N}$}

$\% N D F L M=$

atom $\%{ }^{15} \mathrm{~N}$ excess of green manure $\mathrm{N}$

where atom\% excess of ${ }^{15} \mathrm{~N}$, both for inorganic and legume $\mathrm{N}$, was obtained by subtracting the natural abundance of ${ }^{15} \mathrm{~N}\left(0.366 \%{ }^{15} \mathrm{~N}\right)$ from the abundance of the appropriate legume source (e.g., roots, above-ground parts).

The amount of inorganic $\mathrm{N}$ derived from the legume manure (NDFLM) was obtained as follows [2]:

$\mathrm{NDFLM}=\left(\% \mathrm{NDFLM}{ }^{*} \mathrm{NT}\right) / 100$

where NT = soil total inorganic N.

The amount of inorganic $\mathrm{N}$ derived from the native soil N (NS) was calculated as follows [3]:

$\mathrm{NS}=\mathrm{NT}-\mathrm{NDFLM}$

\section{RESULTS AND DISCUSSION}

The concentration of ${ }^{15} \mathrm{~N}$ was higher for labeled sunnhemp (4.337 atoms \%) than for labeled velvet bean (3.177 atoms \%), due to differences in the ${ }^{15} \mathrm{~N}$ symbiotical fixation between the two species during their growth period. Nutrient contents in the used plant material are presented in Table 1. Velvet bean had a higher $\mathrm{N}$ content for both, above-ground parts $\left(27 \mathrm{~g} \mathrm{dm}^{-3}\right)$ and roots $(28 \mathrm{~g}$ $\mathrm{dm}^{-3}$ ), and the highest yield of dry mass for both, aboveground part and the roots, resulting in a lower ${ }^{15} \mathrm{~N}$ labelling (Ambrosano et al., 1997). The bean residue had the lowest $\mathrm{N}$ concentration $\left(8 \mathrm{~g} \mathrm{dm}^{-3}\right)$ because it was the trash left over after grain harvesting. Slight differences were found among of the green manure nutrient contents and $\mathrm{C} / \mathrm{N}$ ratio, except for $\mathrm{P}$, with significant lower concentrations in the bean residue and in the sunnhemp, and for $\mathrm{Mn}$, with significant higher contents in the velvet bean. The bean residue also had the lowest micronutrient contents. Values observed are in agreement with those obtained by Tanaka et al. (1992) for green manure produced in the field.

After seven days of incubation, the total amounts inorganic-N (NT) produced with the green manures and the control treatment were similar (Table 2). These results suggest that during this period there was no net immobilization of inorganic- $\mathrm{N}$, since the amounts of $\mathrm{N}$ mineralized from the plant material predominated over that of the native soil $\mathrm{N}$. However, this was not true for the bean residue treatment, which had a higher $\mathrm{C} / \mathrm{N}$ ratio (45), indicating that immobilization continued over the whole incubation period. Velvet bean had significantly higher contents of total inorganic-N (NT) in relation to sunnhemp after 14 days of incubation.

In a general way, the amount of plant material added to the soil, as well as the amount of $\mathrm{N}$ added by the green manures, generated enough inorganic $\mathrm{N}$ so that mineralization predominated over immobilization.

The $\mathrm{N}$ mineralized from the soil stock (NS) was lower for the treatments with green manure than for the control treatment (NT=NS). Similar results were obtained by Jans Hammermeister et al. (1993a), who observed a higher degree of mineralization of $\mathrm{N}$ from the added plant material, preventing the microbial mineralization of the $\mathrm{N}$ from the original organic matter. On the other hand, our results disagree with those of other experiments in which the addition of inorganic $\mathrm{N}$ caused an "aparent" higher mineralization of soil organic matter (Calvache Ulloa, 1982) a phenomenon known as "Priming effect" (Fried \& Broeshart, 1974), and currently called ANI, "Added Nitrogen Interaction" (Jenkinson et al., 1985; Hart et al., 1986; Rao et al., 1992).

The above-ground part of velvet bean resulted in higher concentration of soil inorganic $\mathrm{N}$ during the whole incubation period as compared to the other green manures (Table 3). Velvet bean and sunnhemp initially had a similar $\mathrm{N}$ mineralization rate, but afterwards $\mathrm{N}$ mineralization from velvet bean was higher and occurred for a longer period. Inorganic $\mathrm{N}$ supply can be considered to be steady, since there were no plants to take up $\mathrm{N}$ in this form. Other researchers, when comparing highly soluble and readily available inorganic $\mathrm{N}$ sources, found that the maintenance of a steady mineralization is a determinant aspect for the differentiation of the green manure N (Ambrosano, 1989; Calvache Ulloa et al., 1982).

Table 1 - Concentration of macro and micronutrient contents, and $\mathrm{C} / \mathrm{N}$ ratio for the above-ground parts $(A P)$ and roots $(R)$ of velvet bean, sunnhemp and bean residue.

\begin{tabular}{|c|c|c|c|c|c|c|c|c|c|c|c|}
\hline Legumes & $\mathrm{N}$ & $\mathrm{P}$ & K & $\mathrm{Ca}$ & $\mathrm{Mg}$ & $\mathrm{Fe}$ & $\mathrm{Mn}$ & $\mathrm{Zn}$ & $\mathrm{Cu}$ & $\mathrm{B}$ & $\mathrm{C} / \mathrm{N}$ \\
\hline & \multicolumn{5}{|c|}{ - } & \multicolumn{6}{|c|}{--:-'- } \\
\hline Velvet bean - AP & 27 & 31 & 102 & 158 & 30 & 297 & 1133 & 66 & 9 & 50 & 15 \\
\hline Velvet bean - R & 28 & 32 & 92 & 61 & 53 & 6285 & 1042 & 124 & 19 & 37 & 12 \\
\hline Sunnhemp - AP & 16 & 18 & 71 & 80 & 35 & 111 & 280 & 31 & 5 & 37 & 25 \\
\hline Sunnhemp - R & 12 & 16 & 41 & 41 & 20 & 6078 & 339 & 45 & 10 & 41 & 25 \\
\hline Bean residue & 8 & 4 & 141 & 47 & 34 & 97 & 17 & 11 & 2 & 21 & 45 \\
\hline
\end{tabular}

Scientia Agricola, v.60, n.1, p.133-137, Jan./Mar. 2003 
All the treatments contributed steadily to provide inorganic-N to the soil, except velvet bean (AP) and bean residue, which gradually increased inorganic $N$ contents along the incubation period (Table 4). For the bean residue, immobilization was found to be more intense in the first weeks after incubation, releasing lately the nitrogen. The bean residue had a higher $\mathrm{C} / \mathrm{N}$ ratio (45), resulting in the immobilization of inorganic $\mathrm{N}$.

An incubation period of 49 days is recommended before growing a crop following common bean trash incorporation because of the slow mineralization of organic N.
The highest mineralization rate of total inorganic $\mathrm{N}$ occurred in the Paleudalf (Table 4). However, the bean residue showed similar values for both soils. The Paleudalf had also the highest concentrations of $\mathrm{N}$ derived from the plant material, except for roots, that contributed similarly in both soils. Velvet bean was the treatment that mostly contributed to the inorganic $\mathrm{N}$ content of both soils, followed by sunnhemp, bean residue, and legume roots.

The Eutrudox has a higher clay content which has a protective action on organic matter making it less available for the activity of microorganisms. The soil analysis showed a higher organic matter content in the

Table 2 - Total mineralized $\left(\mathrm{NH}_{4}-\mathrm{N}\right.$ and $\mathrm{NO}_{3}-\mathrm{N}$ ) nitrogen (NT), derived from legume manure (NDFLM) and derived from soil (NS), for treatments with legumes and control, after 49 days of incubation. Means were calculated for two soils.

\begin{tabular}{|c|c|c|c|c|c|c|c|c|c|c|}
\hline \multirow{2}{*}{$\begin{array}{l}\text { Incubation } \\
\text { Period }\end{array}$} & \multicolumn{3}{|c|}{ Sunnhemp } & \multicolumn{3}{|c|}{ Velvet bean } & \multicolumn{3}{|c|}{ Bean residue } & \multirow{2}{*}{$\begin{array}{l}\text { Control } \\
\mathrm{NS}=\mathrm{NT}\end{array}$} \\
\hline & NT & NDFLM & NS & NT & NFDLM & NS & NT & NDFLM & NS & \\
\hline & -- & 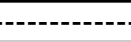 & $\cdots$ & $-\cdots$ & $-\cdots---m g$ & $\mathrm{~kg}^{1}$ & 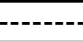 & ---- & 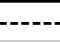 & ...... \\
\hline 7 & $51 \mathrm{a}$ & $17 \mathrm{~A}$ & 34 & $53 a$ & $22 A$ & 31 & $6 \mathrm{c}$ & $1 \mathrm{~B}$ & 5 & $47 a$ \\
\hline 14 & $49 \mathrm{~b}$ & $16 \mathrm{~B}$ & 33 & $63 \mathrm{a}$ & $27 \mathrm{~A}$ & 36 & $14 \mathrm{c}$ & $3 \mathrm{C}$ & 11 & $44 \mathrm{~b}$ \\
\hline 21 & $55 \mathrm{~b}$ & $18 \mathrm{~B}$ & 37 & $73 a$ & $38 \mathrm{~A}$ & 35 & $12 \mathrm{c}$ & $3 \mathrm{C}$ & 9 & $44 \mathrm{~b}$ \\
\hline 28 & $53 \mathrm{~b}$ & $17 \mathrm{~B}$ & 36 & $77 \mathrm{a}$ & $40 \mathrm{~A}$ & 37 & $17 \mathrm{C}$ & $5 \mathrm{C}$ & 12 & $47 \mathrm{~b}$ \\
\hline 35 & $45 \mathrm{~b}$ & $17 \mathrm{~B}$ & 28 & $63 a$ & $36 \mathrm{~A}$ & 27 & $21 \mathrm{c}$ & $6 \mathrm{C}$ & 15 & $50 \mathrm{~b}$ \\
\hline 42 & $41 \mathrm{~b}$ & $17 \mathrm{~B}$ & 24 & $56 a$ & $28 \mathrm{~A}$ & 28 & $22 c$ & $6 \mathrm{C}$ & 16 & $41 \mathrm{~b}$ \\
\hline 49 & $51 \mathrm{~b}$ & $23 B$ & 28 & $67 a$ & $37 \mathrm{~A}$ & 30 & $32 \mathrm{c}$ & $9 \mathrm{C}$ & 23 & $52 \mathrm{~b}$ \\
\hline
\end{tabular}

Means in the rows followed by different letters are different according to the Tukey test at $5 \%$; lower case letters compare NT means, and capital letters are for inorganic-N NDFLM. C.V. 21.9\% (NT) and 8.2\% (NDFLM).

Table 3 - Amounts of inorganic $\mathrm{N}$ mineralized during a 49 day incubation period, derived from either the above-ground part $\mathrm{N}$ (NPA) or the roots (NR) of ${ }^{15} \mathrm{~N}$ labeled green manures and bean residue Mean values for two soils.

\begin{tabular}{|c|c|c|c|c|c|c|c|c|c|c|}
\hline \multirow{3}{*}{$\begin{array}{l}\text { Incubation } \\
\text { Period } \\
\text { Days }\end{array}$} & \multicolumn{4}{|c|}{ Sunnhemp } & \multicolumn{4}{|c|}{ Velvet bean } & \multirow{2}{*}{\multicolumn{2}{|c|}{$\begin{array}{l}\text { Bean } \\
\text { Residue }\end{array}$}} \\
\hline & \multicolumn{2}{|c|}{ NPA } & \multicolumn{2}{|c|}{ NR } & \multicolumn{2}{|c|}{ NPA } & \multicolumn{2}{|c|}{ NR } & & \\
\hline & $\%$ & $\mathrm{mg} \mathrm{kg}^{-1}$ & $\%$ & $\mathrm{mg} \mathrm{kg}^{-1}$ & $\%$ & $\mathrm{mg} \mathrm{kg}^{-1}$ & $\%$ & $\mathrm{mg} \mathrm{kg}^{-1}$ & $\%$ & $\mathrm{mg} \mathrm{kg}^{-1}$ \\
\hline 7 & $33.8 \mathrm{a}$ & $15.8 \mathrm{a}$ & $2.5 \mathrm{c}$ & $1.5 \mathrm{~b}$ & $38.0 \mathrm{a}$ & $18.3 \mathrm{a}$ & $6.0 \mathrm{c}$ & $3.5 \mathrm{~b}$ & $17.8 \mathrm{~b}$ & $1.1 \mathrm{~b}$ \\
\hline 14 & $34.7 \mathrm{a}$ & $14.9 \mathrm{~b}$ & $2.5 \mathrm{~d}$ & $1.4 \mathrm{~d}$ & $38.9 \mathrm{a}$ & 23.8 a & $5.5 c$ & $3.5 \mathrm{~cd}$ & $18.3 \mathrm{~b}$ & $2.8 \mathrm{c}$ \\
\hline 21 & $37.0 \mathrm{~b}$ & $16.6 \mathrm{~b}$ & $2.7 \mathrm{e}$ & $1.8 \mathrm{c}$ & $43.9 \mathrm{a}$ & $32.4 \mathrm{a}$ & $7.0 \mathrm{~d}$ & $5.2 \mathrm{c}$ & $24.1 \mathrm{C}$ & $3.3 \mathrm{c}$ \\
\hline 28 & $37.2 \mathrm{~b}$ & $15.1 \mathrm{~b}$ & $2.8 \mathrm{e}$ & $1.9 \mathrm{c}$ & $45.2 \mathrm{a}$ & $34.4 \mathrm{a}$ & $6.5 \mathrm{~d}$ & $5.1 \mathrm{c}$ & $26.1 \mathrm{c}$ & $4.7 \mathrm{c}$ \\
\hline 35 & $36.4 \mathrm{~b}$ & $15.3 b$ & $2.8 \mathrm{e}$ & $1.4 \mathrm{C}$ & $44.5 \mathrm{a}$ & $32.4 \mathrm{a}$ & $6.2 \mathrm{~d}$ & $3.4 \mathrm{c}$ & $26.1 \mathrm{C}$ & $5.7 \mathrm{c}$ \\
\hline 42 & $37.5 \mathrm{a}$ & $16.0 \mathrm{~b}$ & $3.0 \mathrm{~d}$ & $1.3 \mathrm{~d}$ & $41.8 \mathrm{a}$ & $23.1 \mathrm{a}$ & $7.8 \mathrm{c}$ & $4.4 \mathrm{~cd}$ & $27.2 \mathrm{~b}$ & $6.2 \mathrm{c}$ \\
\hline 49 & $38.1 \mathrm{~b}$ & $21.5 b$ & $3.1 \mathrm{e}$ & $1.4 \mathrm{~d}$ & $46.5 \mathrm{a}$ & $32.0 \mathrm{a}$ & $6.7 \mathrm{~d}$ & $4.6 \mathrm{~cd}$ & $26.7 \mathrm{C}$ & $8.7 \mathrm{c}$ \\
\hline $\mathrm{Fl}^{(1)}$ & ns & ns & * & ns & * & * & ns & ns & ns & * \\
\hline $\mathrm{R}^{2}$ & - & - & 0.28 & - & 0.30 & 0.16 & - & - & - & 0.35 \\
\hline
\end{tabular}

Means followed by different lower case letters in the same column are different (Tukey $P<0.05$ ).

(1) F-test, linear effect. C.V.=8.2\%.

Table 4 - Amount of total mineralised $\left(\mathrm{NH}_{4}-\mathrm{N}\right.$ and $\left.\mathrm{NO}_{3}-\mathrm{N}\right)$ nitrogen (NT), and percentage of mineralised $\mathrm{N}$ derived from the above-ground part (AP) and roots (R) of ${ }^{15} \mathrm{~N}$ labeled legumes, and bean residue (NDFLM), in both soils (LV and Paleudalf). Mean values after a 49 day incubation.

\begin{tabular}{|c|c|c|c|c|}
\hline \multirow[t]{2}{*}{ Treatment } & \multicolumn{2}{|c|}{ NT } & \multicolumn{2}{|c|}{ NDFLM } \\
\hline & Eutrudox & Paleudalf & Eutrudox & Paleudalf \\
\hline & 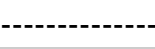 & ---------- & & \\
\hline Sunnhemp - AP & $38.1 \mathrm{bC}$ & $50.7 \mathrm{aC}$ & $31.2 \mathrm{bB}$ & $41.7 \mathrm{aB}$ \\
\hline Sunnhemp - R & $49.0 \mathrm{bB}$ & $62.2 \mathrm{aB}$ & $2.5 \mathrm{aE}$ & $3.0 \mathrm{aE}$ \\
\hline Velvet bean - AP & $56.3 \mathrm{bA}$ & $72.2 \mathrm{aA}$ & $37.2 \mathrm{bA}$ & $48.2 \mathrm{aA}$ \\
\hline Velvet bean - R & $59.0 \mathrm{bA}$ & $71.8 \mathrm{aA}$ & $6.0 \mathrm{aD}$ & $7.0 \mathrm{aD}$ \\
\hline Bean residue & $21.7 \mathrm{aD}$ & $21.7 \mathrm{aD}$ & $18.7 \mathrm{bC}$ & $28.9 \mathrm{aC}$ \\
\hline
\end{tabular}

Means followed by different letters are different (Tukey $P<0.05$ ); capital letters in the columns treatments and lower case letters on the rows soils. C.V. $=21.9 \%$ (NT) e $8.2 \%$ (NDFLM). 
Eutrudox $\left(30 \mathrm{~g} \mathrm{dm}^{-3}\right)$ than in Paleudalf $\left(10 \mathrm{~g} \mathrm{dm}^{-3}\right)$. According to Stevenson (1982), more than $90 \%$ of the $N$ in topsoil of most soils is in the organic form. Ladd et al. (1983) also found, for a soil with low $\mathrm{N}$ content, a higher mineralization rate. In this case, about $13 \%$ of the inorganic $\mathrm{N}$ derived from the added plant residue, contrasting with the $5 \%$ found in a N-richer soil. JansHammermeister et al. (1993a) studied $\mathrm{N}$ mineralization rates in two soils amended with pea residues, and observed a higher rate associated to soils to low clay content.

\section{CONCLUSIONS}

Velvet bean green manure, especially the aboveground parts, presented the greatest contribution to the inorganic $\mathrm{N}$ in the soil.

Common Bean trash residue added to the soil caused the immobilization of inorganic N.

Green manures incorporated to the soil were more intensively mineralized, preventing the soil native organic $\mathrm{N}$ to be mineralized.

\section{Paleudalf Soil.}

Legume $\mathrm{N}$ mineralization was higher in the

\section{ACKNOWLEDGMENTS}

To the technicians Paulo Eduardo Magalhães, Ocimara Aparecida Alves, Virginia Maria Barbosa Villar, Valéria Garcia, Maria Jussara F.R. Vieira and Luzia de Fátima da Silva by for sample preparation and analyzes; and to the technicians, José Aurélio Bonassi, Toninha, Isabel and Geraldo for isotopic analyses; and to Miguel and Silvia, for the statistical analysis. Project financially supported by FAPESP-Temático (93/0691-8) AIEA, BRA/5/029, Vienna.

\section{REFERENCES}

AMATO, M.; LADD, J.N. Decomposition of ${ }^{14} \mathrm{C}$-labeled glucose and legume material in a range of soils: Properties influencing the accumulation of organic residues and microbial biomass C. Soil Biologycal and Biochemistry, v.24, p.455-464, 1992.

AMATO, M.; LADD, J.N.; ELLINGTON, A.; FORD, G.; MAHONEY, J.E.; TAYLOR, A.C.; WASGOTT, D. Decomposition of plant material in Australian soils. IV. Decomposition in situ of ${ }^{14} \mathrm{C}$ and ${ }^{15} \mathrm{~N}$-labeled legume and weat materials in a range of southern Australian soils. Australian Journal of Soil Research, v.25, p.95-105, 1987.

AMBROSANO, E.J. Avaliação do crescimento e aproveitamento de fertilizante nitrogenado pelo capim colonião var. Tobiatã em diferentes épocas. Piracicaba, 110p. 1989. Dissertação (Mestrado) - Escola Superior de Agricultura "Luiz de Queiroz", Universidade de São Paulo.

AMBROSANO, E.J. Dinâmica do nitrogênio dos adubos verdes, crotalária júncea (Sunnhemp) e mucuna-preta (Mucuna aterrima), em dois solos cultivados com milho. Piracicaba, 1995. 83p. (Tese de Doutorado) - Escola Superior de Agricultura "Luiz de Queiroz", Universidade de São Paulo.

AMBROSANO, E.J.; TRIVELIN, P.C.O.; MURAOKA, T. Técnica para marcação dos adubos verdes crotalária júncea e mucuna-preta, $c 0{ }^{15} \mathrm{~N}$ para estudos de dinâmica do nitrogênio. Bragantia, v.56, p.219-224, 1997.

AZAM, F.; MALIK, K.A.; SAJJAD M.I. Transformations in soil and availability to plants of ${ }^{15} \mathrm{~N}$ applied as inorganic fertilizer and legume residues. Plant and Soil, v.86, p.3-13, 1985.

AZAM, F.; MALIK, K.A.; SAJJAD M.I. Uptake by wheat plants and turnover within soil fractions of residual $\mathrm{N}$ from leguminous plant material and inorganic fertilizer. Plant and Soil, v.95, p.97-108, 1986.
BARTHOLOMEW, W.V. Mineralization and immobilization of nitrogem in the decomposition of plant and animal residues. BARTHOLOMEW, W.V.; CLARK, F.E. In: Soil Nitrogen (Ed.), Madison: ASA, 1965. p.287-306.

BURESH, R.J.; AUSTIN, E.R.; CRASWELL, E.T. Analytical methods in ${ }^{15} \mathrm{~N}$ research. Fertilizer Research, v.3, p.337-62, 1982.

CALVACHE ULLOA, A.M.; LIBARDI, P.L.; REICHARDT, K. Utilização do nitrogênio fertilizante por dois híbridos de milho. Campinas: Fundação Cargill, 1982. 66p.

CANTARELLA, H. Calagem e adubação do milho. In SIMPÓSIO SOBRE FATORES QUE AFETAM A PRODUTIVIDADE DO MILHO E SORGO, Vitória, 1990. Cultura do Milho: fatores que afetam a produtividade. Piracicaba: Potafos, 1993. p.301.

EMPRESA BRASILEIRA DE PESQUISA AGROPECUÁRIA. Centro Nacional de Pesquisa de Solos. Sistema brasileiro de classificação de solos. Brasília: EMBRAPA, CNPSO, 1999. 412p.

FRIED, D. M. ; SOPER, R.J. ; BROESHART, H. ${ }^{15} \mathrm{~N}$ labeled single-treatment fertility experiments. Agricultural Journal, v.67, p.393-396, 1975.

FRIED, D.M.; BROESHART, H. Priming effect of nitrogen fertilizer on soil nitrogen. Proceedings of the Soil Science Society of America, v.38, p.858-864, 1974.

HART, P.B.S.; RAYNER, J.H.; JENKINSON, D.S. Influence of pool substitution on the interpretation of fertilizer experiments with ${ }^{15} \mathrm{~N}$. Journal of Soil Science. v.37, p.388-403, 1986.

INTERNATIONAL ATOMIC ENERGY AGENCY. Tracer manual on crops and soils. Viena: IAEA, 1976. 277p.(Tecnical Reports Series, 171)

JANS-HAMMERMEISTER, D.C.; McGILL, W.B.; JENSEN, T.L. Nitrogen accumulations and relative rates of mineralization in two soils following legume green manuring, Canadian Journal of Soil Science, v.74, p.23-28. 1993a.

JANS-HAMMERMEISTER, D.C.; McGILL, W.B.; JENSEN, T.L. Dynamics of ${ }^{15} \mathrm{~N}$ in two soil-plant systems following incorporation of $10 \%$ bloom and full bloom field pea. Canadian Journal of Soil Science, v.74, p.99-107, 1993b.

JENKINSON, D.S.; AYANABA, A. Decomposition of carbon-14 labeled plant material under tropical conditions. Soil Science Society of America Journal, v.41, p.912-915, 1977

JENKINSON, D.S.; FOX, R.H.; RAYNER, J.H. Interaction between fertilizer nitrogen and soil nitrogen- The so- called «Priming» effect, Journal of Soil Science, v.36, p.425-444, 1985.

LADD, J.N.; OADES, J.M.; AMATO, M. Microbial biomass formed from 14C, $15 \mathrm{~N}$-labeled plant material decomposing in soils in the field. Soil Biology and Biochemistry, v.13, p.119-126, 1981a.

LADD, J.N.; OADES, J.M.; AMATO, M. Distribution and recovery of nitrogem from legume residues decomposing in soils sown to wheat in the field. Soil Biology and Biochemistry, v.13, p.251-256, 1981b.

LADD, J.N.; AMATO, M.; JACKSON, R.B.; BUTLER, J.H.A. Utilization by wheat crops of nitrogen from legume residues decomposing in soils in the field. Soil Biology and Biochemistry, v.15, p.231-238, 1983.

MULLER, M.M.; SUNDMAN, V. The fate of nitrogen $(15 \mathrm{~N})$ released from different plant materials during decomposition under field conditions. Plant and Soil, v.105, p.133-139, 1988.

MURAOKA, T. Utilização de técnicas nucleares nos estudos da adubação verde. In: ENCONTRO SOBRE ADUBAÇÃO VERDE, Rio de Janeiro, 1983. Anais. Campinas: Fundação Cargill, 1984. p.330.

RAIJ, B. van. Avaliação da fertilidade do solo. Piracicaba: Instituto da Potassa \& Fosfato, 1981. 142p.

RAO, A.C.S.; SMITH, J.L.; PARR, J.F.; PAPENDICK, R.J. Considerations in estimating nitrogen recovery efficiency by the difference and isotopic dilution methods. Fertilizer Research, v.33, p.209-217, 1992.

RITTENBERG, D. The preparation of gas sample for mass-spectrometric analysis. In WILSON, D.W. (Ed). Preparation and measure of isotopic tracers. Michigan: Ann Arbor, 1946. p.31.

SILVA, R. Potencial da mucuna preta como adubo verde para o arroz-desequeiro em latossolo amarelo da amazônia. Piracicaba, 1991.136p. Tese (Doutorado) - Escola Superior de Agricultura "Luiz de Queiroz", Universidade de São Paulo.

SMITH, J.H.; LEEG, J.O.; CARTER, J.N. Equipment on ${ }^{15} \mathrm{~N}$ analysis of soil and plant material with the mass spectrometer. Soil Science, v.96, p.313318, 1963.

STEVENSON, F.J. Nitrogen in agricultural soils, Madison: ASA, 1982. p.67122: Organic forms of soil nitrogem.

TA, T.C.; FARIS, M.A. Availability of N from $15 \mathrm{~N}$ labeled alfafa residues to three succeeding barley crops under field conditions. Soil Biology and Biochemistry, v.22, p.835-838, 1990.

TANAKA, R.T.; MASCARENHAS, H.A.A.; DIAS, O.S.; CAMPIDELLI, C.; BULISANI, E.A. Cultivo da soja após incorporação de adubo verde e orgânico. Pesquisa Agropecuária Brasileira, v. 27, p.1477-1483, 1992.

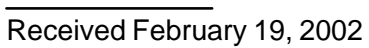

